\title{
Harvard meets the crisis: U.S. fiscal policy in the 1930s and the political economy of Lauchlin B. Currie, Jacob Viner, John H. Williams and Harry D. White
}

\author{
Michele Alacevich, Pier Francesco Asso, Sebastiano Nerozzi*
}

\begin{abstract}
:
The paper aims to describe the contribution of four Harvard economists to the interpretation of the Great Depression and the policy decision making from 1933 to 1938. Lauchlin B. Currie, Jacob Viner, John H. Williams, Harry D. White, eminent scholars in the field of monetary and international economics, were deeply involved in policy decisions during the New Deal. In our synoptic analysis we will benefit from extensive scholarly work that has been provided in the last few years. We shall examine the extensive biographical connection between Currie, Viner, White and Williams with special regard to their common training at Harvard. Then we shall compare their interpretations of the causes of crisis and their proposals in fiscal, monetary and banking policy. Finally, we shall describe their advisory activity in the Roosevelt administration and try to assess their influence.
\end{abstract}

Keywords: Great Depression; Monetary Theory; Monetary Policy; Fiscal Policy, Keynesism

JEL Classification: B22, E32, E58, E63, N12

\footnotetext{
Michele Alacevich: Harvard University, Center for European Studies; Pier Francesco Asso, University of Palermo, Department of European Studies; Sebastiano Nerozzi, Catholic University of Milan, Department of Economics. While the views and the research work underpinning this paper have been deeply shared by the three authors, sections 2-3 were written by Michele Alacevich, section 4 by Pier Francesco Asso and sections 5-6-7 by Sebastiano Nerozzi. This paper was presented at the Storep Conference in Florence, June 2009, and at the HES Conference in Syracuse, June 2010. We wish to express our gratitude to all participants for the comments we received. A special thanks is owed to Marianne Jonhson and Luca Fiorito for their suggestions. The usual disclaimer applies.
} 


\section{Introduction}

When studying the causes of the Great Depression, the so-called Chicago School of Political Economy has traditionally been looked at as a key reference point. In the past few years, however, further studies have highlighted important contributions coming from different intellectual environments, especially Harvard (see, for example, Laidler and Sandilands (2002 [2003]). In particular, the four Harvard economists Jacob Viner, John H. Williams, Lauchlin B. Currie, and Harry D. White, have been studied for their close connections with the New Deal Administration and for offering a very innovative analysis of the Depression.

While the life and works of Currie and White have been widely studied, Williams and Viner have traditionally been acknowledged as influential figures only in general studies of the New Deal, but their activity as public advisers has not been the subject of in-depth research. ${ }^{1}$ Recent papers based on archival sources have provided clear evidence of extensive collaboration and overlapping ideas between these four economists (Sandilands 2004, Asso and Fiorito 2009, Nerozzi 2009). Yet, little attention has been devoted to a systematic comparison of their analysis of the Great Depression and their views on the pros and cons of fiscal and monetary policy.

Our aim is to adopt a comparative approach to show the many points in common - and yet some important differences - among their interpretations of the Great Depression. In particular, we will describe how Viner, Williams, Currie and White's common training, personal friendship, and shared vision on monetary, fiscal and banking matters produced an innovative analysis of the Great Depression. Their approach ultimately influenced the Fed and the U.S. Administration, and informed government policies to address the Depression.

\footnotetext{
${ }^{1}$ On Currie and White, see Rees 1973, Boughton 2005, Sandilands 1990, and Alacevich 2005 and 2009; on Williams and Viner, see Stein 1969, Barber 1996, and Meltzer 2003.
} 
Our interest focuses on how the views common to these four economists took shape, how they evolved in a similar manner despite the many differences that made the thought of each of them peculiar and well-defined, and how their ideas travelled with them to Washington, DC and influenced processes of policymaking in the capital. Valdemar Carlson, himself a student of economics at Harvard in the 1920s, claimed years ago that there was actually no specific reason why a number of Harvard economists moved to Washington's federal government. Certainly, according to Carlson, they were not selected based on their belonging to a supposed Harvard school of thought that, in his opinion, did not actually exist. As Carlson put it, the reason for the large presence of former Harvard students in Washington had to do with the lack of alternatives for smart and promising students: "Trained brain power is always a scarce commodity, and particularly during a period of social change it is difficult to find people with the requisite ability and imagination to engineer institutional adjustments. In the 1920 's there were not many first-class graduate schools and those that had an outstanding reputation tended to attract the more able students. It was because outstanding students were attracted to Harvard that so many of that university's economists played such an important role in helping to fashion the New Deal reforms" (Carlson 1968, p. 112). ${ }^{2}$ A study by David Laidler and Roger Sandilands, on the contrary, has tracked the monetary roots of the Chicago School back to what they claim are its real Harvard origins (Laidler and Sandilands 2002 [2003]).

We adopt a different perspective. As it will become apparent below, we share a common analysis with Laidler and Sandilands on these four economists. Our focus, however, is on how the common core of ideas shared by these economists took shape since their doctoral studies and evolved - and differentiated - in their subsequent activity of scholars and public servants in Washington, DC. We will try to show that that common core of ideas was an important factor in their public

\footnotetext{
${ }^{2}$ For another analysis of Harvard's Department of Economics, see Mason 1982.
} 
activity, the policy making process they contributed to shape, and the way their professional careers evolved.

\section{A Harvard (minority) tradition}

Scholarly interest in Viner, Williams, Currie and White grew in connection with the debate over the origins and nature of the Chicago School of Political Economy. According to Laidler and Sandilands (2002 [2003]), the main ideas at the roots of the Chicago monetary tradition were actually born elsewhere, primarily in Harvard. Lauchlin Currie, who studied at Harvard with Allyn A. Young, Ralph G. Hawtrey and John H. Williams, is credited for being a precursor of Milton Friedman and Anna Schwartz's analysis of the depression (Friedman and Schwartz 1963). Already in 1934, Currie had acknowledged the importance of the contraction in money supply as a cause of the depression, and considered the Federal Reserve's lack of interest in this issue as the main culprit in the onset and deepening of the depression. John H. Williams, professor at Harvard, played a leading role in the discussion and approval of the so-called Chicago manifesto, which called for a bold program of monetary expansion and public works; this public statement was endorsed by twenty-four economists gathered at the Harris Foundation Conference in Chicago in January 1932. Jacob Viner, a former Harvard Ph.D. graduate and a prominent figure of the Chicago department of economics, was regarded by Friedman himself as one of the forefathers of the Chicago monetary tradition. Harry D. White, then a little-known economics instructor at Harvard University, contributed with Currie and Paul T. Ellsworth to a memorandum presented by Williams at the Chicago conference (Laidler and Sandilands 2002 [2003]). Together with Paul T. Ellsworth, Albert G. Hart, Alan Sweezy and Martin Krost, White and Williams joined forces in campaigning for an emergency program of monetary stimuli and fiscal intervention. 
The radical and innovative ideas of the younger generation of Harvard economists enjoyed the support of John $\mathrm{H}$. Williams, but clashed with the more conservative positions of the senior members of the faculty, who decidedly sided against any sort of State intervention. While Williams taught at Harvard for most of his career and was appointed in 1947 as the first Dean of the Harvard Business School, the group of young heretics around him rapidly became outcast: White and Currie joined the Roosevelt Administration; Hart, a former undergraduate student of Currie at Harvard, gained his Ph.D. at Chicago and started a successful academic career at Columbia; Alan Sweezy, fired from Harvard in 1937, served in the Work Progress Administration (1938) and the Fed (1939), before returning to academia, first as associate professor at Williams College and then as full professor at Caltech (1949). Viner taught at Chicago until 1946 when he moved to Princeton. From 1933 to 1945 he served at the Treasury as a special consultant to Secretary Henry Morgenthau Jr. and subsequently, after 1943, became an advisor to the State Department.

Currie, White, Hart and Sweezy were recruited in Viner's "Freshmen brain trust" at the Treasury in the summer 1934. This group was entrusted with advising on the most important banking and monetary issues the country faced at the time. ${ }^{3}$ The gathering of this group of young Harvard economists under Viner's guidance allowed new ideas on central banking, monetary and fiscal policy to circulate in the Administration. Eventually, these ideas found their way in legislation and policy decision-making. In May 1933, Williams was appointed as expert economist to the New York Fed, where he became vice-chairman in 1936. His influence spread across the Treasury and other agencies. Williams and Viner,

\footnotetext{
${ }^{3}$ Viner asked Currie to draft a proposal for reforming the banking system of the United States. Many other prominent reports on related topics were produced around the same period, including: Edward C. Simmons, "The Currency System"; Benjamin Caplan, "Branch banking"; Albert G. Hart, "Federal credit institutions"; Lauchlin Currie, "Monetary control in the United States" and "Deposit Insurance"; Alan R. Sweezy, "Objectives and criteria of monetary policy"; Harry D. White, "Selection of a monetary standard for the United States"; and M.H. Riley, "Bank examinations and bank reports".
} 
de facto liaison officers between the Treasury and the Fed, were not only personal friends; they also shared common views on monetary and international policy. White was hired at the Treasury and became head of the Division of Monetary Research in 1937. Currie became the closest economic adviser to Marriner Eccles, whom he had met when he was a consultant at the Treasury.

\section{Studying and teaching at Harvard (1914-1933)}

Currie, Viner, Williams and White shared an interest in original research in the field of monetary and international economics and banking, and a methodology that favored extensive data collection and quantitative analysis. This was the result of their training at Harvard University.

Viner, Williams and White wrote their Ph.D. dissertations under the supervision of Frank W. Taussig and each of them prepared a case study on the same general topic: the adjustment mechanism of the balance of payments in presence of capital movements. Viner studied Canada during the prewar years under the gold standard, Williams studied Argentina between 1880 and 1900 under a paper money regime and flexible exchange rates, and White examined France from 1880 to 1913 (Viner 1924; Williams 1920; White 1933). These studies provided an empirical validation of the classical theory of international trade. According to Viner, the case of Canada offered a confirmation of Hume's price-specie flow mechanism, with some qualification due to the working of the flexible banking multiplier and to capital movements: foreign reserves, expansion of bank deposits, and domestic prices moved in the same direction, fostering the adjustment of the balance of trade. In this context, capital movements exerted mainly a stabilizing effect. A huge flow of long-term capital investments gave rise to a fractional demand for short-term reserves in the opposite direction, mainly gold certificates held by Canadian commercial banks in New York, which 
supported the expansion of domestic credit. Changes in foreign deposits abroad played the role of shock absorber, minimizing the movement of specie required to keep the exchange rates within the gold points and adjusting the Canadian balance of trade according to the seasonal fluctuations in the demand for credit. Since Canada had not a central bank at the time, this mechanism seemed to confirm the automatic functioning of the gold standard (for a discussion of this point see Flanders 1989: 228-229).

Williams and White were more critical of the real working of the price-specieflow mechanism. A statistical analysis of the balance of payments and monetary conditions of Argentina confirmed that, in presence of a paper currency, gold movements did not affect the domestic money supply but only the external value of the currency, i.e., its exchange rates; at the same time, the low export elasticity (due to widespread deflation in foreign markets) did not allow exchange rate flexibility to guarantee a smooth adjustment of the balance of trade but stimulated a growing foreign indebtedness. According to Williams, the case of Argentina showed how capital movements could be of a destabilizing nature despite the monetary rules that the country adopted: both under a gold standard and a paper standard, "a rise of prices in one country relative to others may in fact attract capital from abroad. Rising prices usually means rising profits", fostering a cumulative increase in prices, capital inflow and credit expansion (Williams 1932a: 175).

White's study cast further doubts over the traditional views of external adjustment. He noticed that most statistical surveys on domestic prices provided little support for Hume's adjustment mechanism; moreover, long term investments in developing countries were not matched by a parallel increase in export trade. White also noticed that exchange rates movements within the gold points did not affect the balance of trade (Flanders 1989: 237). Most importantly, White underscored the ability of the Bank of France to prevent substantial flows of gold from and to the country, which kept domestic monetary conditions more 
stable. Moreover, White showed that capital flows were endogenously driven by changes in income, consumption and savings, with a greater impact on the balance of payments than changes in the price level. White's adjustment mechanism was very close to Bertil Ohlin's income-expenditure approach, even though he regarded the movements of gold and international lending as the main driving force in the shifts of income and aggregate demand (Flanders 1989: 241).

While these studies drew different conclusions on the effectiveness of the classical adjustment mechanism, they all focused on monetary, financial and banking aggregates to explain the dynamics of domestic prices, real incomes, and the balance of trade. As was typical of Taussig's approach, they thoroughly examined the historical and institutional environment, and the banking and monetary system. The same principle and the same methodological approach were at the center of Currie's Ph.D. dissertation, which focused on the functioning of the U.S. banking system in the post-war years (Currie 1931).

Currie started working on his doctoral dissertation under the tutorship of Allyn A. Young, a pioneer of statistical research on the American banking system during the 1920s. ${ }^{4}$ In 1928 Currie was teaching assistant first to Ralph G. Hawtrey, and later, after the premature death of Allyn Young in March 1929, to John Williams. His Ph.D. thesis was deeply influenced by his tutor and senior professors. Currie focused on the supply of money in the United States from the 1920s. He adopted quite a narrow definition of money, including coins, banknotes and demand deposits, but excluding time and saving deposits, which Currie regarded as idle balances with no circulation and therefore unable to affect aggregate demand.

One of Currie's major accomplishments was the creation of one of the first statistical series of money supply in the United States. It is worth noting that Currie's series differed substantially from the one proposed almost at the same

\footnotetext{
${ }^{4}$ Young $(1927 ; 1928)$. On Young's monetary thought see Mehrling (1997); on Currie's training at Harvard, see Sandilands (1990) and Laidler (1993 [2003]). Young was economic advisor to the Governor of the Federal Reserve of New York, Benjamin Strong (Mehrling 1997: 104).
} 
time by Carl Snyder, a Fed statistician, who included time and saving deposits in his calculation. According to Currie's data, during the 1920s the increase in the money supply had been less than usually believed at that time. Currie's findings, later expanded to cover the early depression years, actually showed that the money supply had ceased to grow already by 1928, and suffered a steep contraction from 1930 to 1932 (Currie 1933a: 86). Currie maintained that the Federal Reserve had failed to understand the need to increase the money supply to mitigate the depression. For the first time, a scholar was charging the Federal Reserve with specific responsibility for having worsened the economic and monetary conditions of the country after the 1929 stock exchange crash. Currie's thesis remained unpublished, but one chapter was published as a separate article in 1934. In it, Currie blamed the almost exclusive attention of the Federal Reserve to the control of domestic security speculation as a major source of its restrictive stance (Currie 1934b). However, according to Currie, the Fed's principal shortcoming was a doctrinal one: the Fed's statute and operations were inspired by the so-called Commercial Loan Theory of Banking. This meant that the Fed saw the primary function of the banks as "meet[ing] the short term borrowing needs of 'legitimate' business" (Currie 1934a: 34). As a consequence, the concerns of the Fed were primarily focused on the composition of banking assets. The supply of money and its connections with money incomes and business activity were essentially ignored. ${ }^{5}$

Currie's criticism of the Commercial Loan Theory of Banking offered arguments similar to those of Williams in his late 1920 s and early 1930 s writings. Williams was familiar with the most recent quantitative work in the field of money

\footnotetext{
${ }^{5}$ Currie defended his dissertation at Harvard University in January 1931 but failed to win the Well prize, which was instead awarded to Currie's classmate and close friend Harry White in 1933. Currie stayed at Harvard as an instructor. He assisted Williams in his famous Money and Banking Course, and was also an assistant to Joseph Schumpeter. In the following years, Currie published several articles based on his Ph.D. dissertation. Frank H. Knight and Jacob Viner, co-editors of the Journal of Political Economy, accepted two of Currie's articles for publication.
} 
and banking, and shared most of the ideas set forth by Currie. ${ }^{6}$ In his 1931 forty page review of Keynes's Treatise on Money, Williams discussed in great detail Keynes's treatment of income-, business- and saving- deposits, assessing their relevance for the business cycle and the level of aggregate demand. Drawing from Currie's data, Williams analysed the deep divergence between the U.S. and the British systems (Williams 1931: 566, nt. 4). Furthermore, his criticism of Keynes's early views on the close relation between the money supply and the structure of interest rates seemed to fit very well in Currie's monetary control framework. For Williams, the connection between interest rates and investment expenditure was weak and uncertain. Accordingly, such an abstract and immaterial concept as the Wicksellian "natural interest rate" could not play a central role in determining the direction and the intensity of business trends and fluctuations (Williams 1931: 578). Monetary forces and the variation of short term interest rates were likely to exert a stronger direct influence on consumers spending, business expectations and investment decisions. Yet, Williams drew a less clear-cut distinction than Currie between the banking aggregates that were a source of spending and those that were not. ${ }^{7}$ At the same time, he insisted that even if central banks could effectively control banking aggregates, they would still not control consumer spending: "in monetary terms, the crux of the matter is that, while banks control the physical quantity of deposits, depositors control the spending of them, and changes in quantity may be offset by changes in velocity or in direction" (Williams 1931: 580).

${ }^{6}$ In his 1931 review of the Treatise, in addition to Hawtrey, Robertson and Pigou, Williams also cited studies of Harold Reed, Calvin Hoover, James Harvey Rogers, William Trufald Foster and Waddill Catchings, and Percey W. Martin. The latter, an almost unknown English author, wrote a book on the "Problem of Maintaining Purchasing Power", which was positively reviewed by Viner in the Journal of Political Economy.

7 Williams agreed with Keynes that demand deposits could contain a part of idle business deposits which were kept idle by firms, as cash reserves, and could be assimilated to saving deposits. As a consequence, as Williams put it, "the total of demand deposits may undergo little change from prosperity to depression, while yet the volume of consumer spending may be profoundly affected" (Williams 1931: 566). See also his treatment of the effects of stock market speculation on demand deposits and consumers spending, which he considered quite complex to determine (Williams 1931: 570-572). 
Williams's dismissal of the quantity theory in its crudest form is even more explicit in his discussion of the problem of price stabilization: "The central bank by its rate controls the size of member banks reserves (if necessary it can control reserves by open market operations); since member banks are always 'loaned up' to reserve limits, a change in reserves will mean a change in the amount of loans, which will mean a change in the amount of deposits; a change in deposits will produce a change in the price level. But this explanation is too simple and begs some important questions" (Williams 1931: 574). Thus, one of the clearest fallacies of the quantity theory was that it assumed other things equal: "Only if velocity remains unchanged will a change in deposits mean a corresponding change in the effective quantity of money, and only if goods remain unchanged will a change in that quantity produce an equal change in prices. Since velocity is subject to change during the business cycle, that proviso is extremely important. And since the change in quantity of deposits proceeds out of a change in quantity of bank loans, the presumption is that more deposits rest on more goods" (Williams 1931: 574-75). Thus, Williams implied that money creation was an endogenous phenomenon, arising from the productive process which in turn regulated the demand for credit. However, "the simple quantitative comparison of money and goods provides no explanation of how money is spent. If to have more money we must have the banks make more loans, who borrows and for what purpose? Different kinds of transactions require different amounts of money and have different degrees of effect upon the price level" (Williams 1931: 575).

Ever since their graduate years at Harvard University, Viner, White, Currie and Williams shared intellectual interests and research methods. Their academic work, as we will see in the next section, later converged and developed into policy. 


\section{Harvard views on the Great Depression}

To compare the views of the four Harvard economists on the onset and spread of the Great Depression, it is useful to review the proceedings of the Harris Foundation Conference, held at the University of Chicago in January 1932 after a few years of deep crisis. Although only Viner and Williams presented research papers at the conference, archival evidence provided by Laidler and Sandilands shows that Currie and White contributed to their works (Laidler and Sandilands 2002 [2003]).

At the conference, Viner argued that those countries that had recently abandoned the gold standard were better off than those that had not. Yet, he refused to suggest that the United States should follow the same path. According to some scholars, Viner's conclusions were conservative: Viner spoke in defence of the gold standard doctrine, dismissing the charges that it was responsible for the crisis. ${ }^{8}$ Instead, the roots of the Depression were to be sought in the powerful deflationary forces acting all over the world in the 1920 s as a consequence of the heavy external imbalances originated by the war and the peace settlement. These forces had taken momentum through an asymmetric adjustment mechanism imposed by surplus countries, which applied self-oriented monetary and commercial policies upon deficit countries. The protectionist policies enacted by the U.S. Government beginning with the Smoot-Hawley Tariff Act - in Viner's analysis - made it more difficult for foreign countries to have access to American financial markets and obtain the dollars needed to finance imports and repay their debts. Even the sharp reversal, in the late 1920s, of the flow of American longterm foreign investments contributed to the accumulation of gold reserves in the U.S. The consequences for many foreign countries were "inadequate gold reserves, a constant threat to the integrity of their currencies and a deflationary pressure on their prices in spite of embarrassingly rigid labour and other costs

8 On this point see Nerozzi 2011. 
and inflexible internal and external public debt burdens" (Viner 1932[1951]: 132).

The single most important symptom of these disequilibria was the concentration of $70 \%$ of the world's stock of gold in only two countries: France and the United States. The gold inflows associated with the U.S. trade surplus not only were not used to expand credit; even worse, they were used for speculative purposes whose only effect was to reinforce the incoming trend of foreign capital:

In the United States the failure of member banks, since 1922, to utilize freely their rediscount privileges with the Federal Reserve banks was one factor tending to prevent the increase in gold reserves from having its expected influence on the volume of business transactions and on the commodity price level. Much of the great increase in bank credit which did take place went into security and real estate speculation instead of into commerce; and while the price of securities and of real estate assuredly rose, the expectation of a still further rise and the increase in call money rates which resulted from the increased stock-market speculation, drew funds to this country instead of driving them out, as high commodity prices would have done (Viner 1932 [1951]: 131).

The first casualties were overseas countries, struggling to defend their stocks of official reserves. But according to Viner, while the accumulation of gold in France was due to institutional factors, in the United States it was attributable to the ominous monetary and commercial policies enacted by the Fed and the Hoover administration. ${ }^{9}$ After 1927 , Viner stated,

The Federal Reserve Board has revealed to the outsider no greater capacity to formulate a consistent policy, unless a program of thrift,

\footnotetext{
${ }^{9}$ See Viner 1932 [1951]: 131-132.
} 
punctuated at intervals by homeopathic doses of belated inflation or deflation and rationalized by declaration of impotence, can be accepted as the proper constituents of central bank policy (Viner 1932 [1951]: 134). ${ }^{10}$

One of the factors that prevented the Fed from effectively stabilizing business conditions was its complex and decentralized institutional structure.

Our central banking organization is over-complex, too decentralized, and too much subject to regional pressure to act quickly and decisively in the international sphere. Moreover, [...] while the New York Federal Bank has made more effort than any other central bank institution to develop a program and a technique of credit control with a view to stabilization, it has at critical moments found itself at cross purposes with, and inhibited from action by, a Federal Reserve Board with an attitude towards its functions resembling with almost miraculous closeness that of Bank of England during its worst period (Viner 1932 [1951]: 134). ${ }^{11}$

10 In a speech delivered the previous summer at Williamstown, Viner had been even more explicit, blaming on the Fed for the dramatic and sudden decline in aggregate demand: "Except under Governor Strong, the Federal Reserve Board has avoided having a definite policy; it has acted in a purely opportunist manner. [...] Many Englishmen feel that the attempt of the Federal Reserve Board from 1927 to 1929 to check the growth of bank credit which was supporting security speculation in the United States was an unfavourable factor for England. It was impossible to distinguish between credit expansion for legitimate business purposes and expansion for speculation. The large demand for both types raised the money rate in the United States, and this drew money from England to this country and checked American foreign investments [...]. Abroad central bankers and economists are unanimous in the view that the Federal Reserve System has missed important opportunities" (Viner 1931: 189).

${ }_{11}$ These arguments anticipated Milton Friedman and Anna Schwartz in their explanation of the Great Depression. After recalling the analysis and policy proposals that Viner had expounded in 1932-1933, Friedman acknowledged Viner as a precursor: "What in the field of interpretation and policy did Keynes have to offer those of us who learned economics at a Chicago that was filled with these views? Can anyone who knows my work read Viner's comments and not see the direct links between them and Anna Schwartz's and my Monetary History (1963) or between them and the empirical Studies on the Quantity Theory of Money (1956)? Indeed [...] I have myself been amazed to discover how precisely it [Viner 1932(1951)] foreshadows the main thesis of our Monetary History for the depression period" (Friedman 1972 [2003]: 156). 
Given the asymmetric and uncooperative way in which the gold standard had been managed, Viner acknowledged that, as later pointed out by many historical reconstructions, many countries could have incurred a lesser degree of suffering, had they "had a well-regulated paper currency instead of adhering to the world's ill-regulated gold standard" (Viner 1932[1951]: 133). ${ }^{12}$ The "golden fetters" had effectively prevented many countries from offsetting the deflationary forces under way, and those who had freed themselves were likely to gain. Yet, Viner's view of the United States was quite different: because the gold reserves of the United States were large enough to allow a substantial expansion of the money supply without seriously threatening convertibility, there was no need for the United States to abandon the gold standard (Viner 1932[1951]: 139).

Viner's critique was shared by other speakers at the Conference, especially by John Williams, who blamed the Fed for its wrong model of banking behaviour and central banking. While Williams did not stress the responsibility of the Fed in the uneven distribution of gold among countries during the 1920s, he added new arguments to Viner's criticism on the credit restriction of 1927-1929:

After 1924, when our gold holdings ceased to grow, demand deposits ceased to expand, but the growth of loans and of time-deposits continued. The phenomenal increase of time-deposits since the war appears to indicate not unwillingness of our banking system to utilize gold but saturation of demand for credit. As bank assets expanded, the public transferred an increasing portion of the resultant deposits to idle deposits; and during the boom of 1928-1929 these deposits, in the form of "loans for others," served to finance security speculation (Williams 1932b, 150).

${ }^{12}$ Among recent scholars, on this point, see for example Bernanke (1995). 
As already pointed out by Keynes, the increase of U.S. interest rates, designed to curb speculation on the stock market, played a major role in worsening monetary and credit conditions at home as well as in many other foreign countries. Banks were held responsible for short-circuiting the credit system. They showed no capacity for influencing the demand for credit and steer it toward higher quality and more productive purposes. According to Williams,

the reserve system met [the boom] with an attempt to discriminate between loans for commercial and loans for speculative purposes. Its complete failure should explode once for all the notion that it is possible to dictate the uses to which credit is put, rather than the quantity of credit for all purposes.

The draining of foreign funds into our stock market seems, without question, to have been one cause of the depression. The most significant aspect of the movement was that it was in response to high money rates ascribable in part to the Reserve banks' efforts to check domestic credit expansion. It revealed clearly how the problem of credit control by central banks has changed since the war (Williams 1932b, 151).

Currie shared similar views. He stated that the restrictive policies enacted by the Fed to control the stock market boom before 1929 had actually missed the target, as higher interest rates ended up undermining business conditions more than financial speculation (Currie 1934b). Currie referred to Keynes's Treatise: to have the occurrence of a boom, it must be assumed that investments exceed savings. But, as Currie put it,

In 1929 the real danger, as we now know, was the very opposite. An expansion of investments was necessary in order to absorb the labor that 
would otherwise lose employment and to increase incomes that were shortly to become deficient relative to output of finished goods [...]. The level of stock prices should not in itself be a matter of concern to the central bank but rather the net effect of speculation in conjunction with other forces, on saving and investments (Currie 1934a: 172-3). ${ }^{13}$

Currie thoroughly discussed Keynes's and Williams's accounts of the likely effects of stock market speculation on the demand for credit, interest rates, and income. He recognized that these effects could only be measured by empirical analysis of a wide set of relevant data, which were not available at the time. Yet, according to Currie, stock market speculation seemed to have been "increasing the effective purchasing power of the community," because while in 1928-1929 the volume of money had declined, the monetary income had been growing "sufficiently to take off a considerably increased flow of goods at stable prices" (Currie 1934a: 151).

Whatever the effect of stock market speculation on the national income, the Fed's monetary policy had precipitated the country in the deepest depression it had ever experienced. As the onset of the crisis was caused by the steep monetary contraction in the means of payments of the country, the way out was to be looked for in a full reversal of that policy.

\footnotetext{
${ }^{13}$ Sandilands underscores that the high place that Currie gave to the relation between saving and investment for monetary policy was influenced by pre-General Theory Keynes. Instead, Currie remained very skeptical of the new definition of savings that Keynes proposed in the General Theory, and of the role of the Keynesian multiplier in bringing about equilibrium between savings and investment via multiple expansion and contraction of income (Sandilands 1990: 36).
} 


\section{Waging for monetary expansion}

According to Williams, the traditional practice of central banking was obsolete in the post-war world. The huge amount of speculative capital movements and the interdependence of central banks as regards their foreign reserves exacerbated the conflict between domestic stabilization and the functioning of the international monetary system. While the Genoa Conference and the stabilization loans of the League of Nations had somehow increased the efficiency and elasticity of the world's money supply, currency reserves held by national central banks in the main international money markets exposed the national banking systems to a high degree of instability: "Unlike the member bank reserves in the central bank," Williams wrote, "they are subject to no legal compulsion and may be withdrawn at the will of the foreign owner. They are, in consequence, highly unstable and are most apt to be withdrawn when they can least be spared. The effect is similar in kind to hoarding, to a run on a bank, or to a wholesale withdrawal of reserves by member banks from the central bank" (Williams 1932: 147). His conclusion was unequivocal: "the transfers of foreign balances can produce a collapse of the international gold standard" (Williams 1932: 147). Central banks were thus forced to have a surplus of reserves above ordinary requirements: only "if Central Banks reserve is large, or if the system utilizes reserve with great economy, the country is free to pursue an internal monetary policy with comparative disregard to external influences" (Williams 1932: 147). Yet, the creation of such a robust shield against capital flights conflicted with the smooth functioning of the gold standard, which was based on the assumption that banks were "loaned up" and properly responded to a change in their reserves.

Williams recognized that, in its first decade of activities, the Fed had managed reserves efficiently. Those past accomplishments, however, contrasted with the poor outcomes of the Fed's policy in the last few years. Traditional 
instruments of monetary policy had failed to smooth the peaks and troughs of the cycle and contrast deflation. All attempts to follow preconceived rules of behavior failed to maintain stability in the money market. The system suffered for the lack of direct intervention and full discretionary powers:

It is this fact, without doubt, which has made the Federal Reserve System since the war the world's most interesting and important laboratory for the study of monetary problems. With a system like ours it is futile to endeavor to establish legal safeguards as substitutes for management. The policy of imposing restraints by such means as narrow interpretations of rediscount eligibility, attempts rigidly to mark off investment from commercial banking, legal preventives of speculative uses of credit is indeed a recognition of the dangers inherent in an economical system as ours. But such a policy does not check expansion and proves injurious when, as recently, the problem is to check deflation. If pushed as far as the Glass committee intended in its original bill, it would seriously impair the money market. The more effective policy, and the only one consistent with the nature of the process of credit creation and diffusion, would seem to be to maintain a broad contact between the central bank and the money market, to endow the central bank with wide powers of discretionary control, and to insist upon their use (Williams 1932b: 155).

Control functions, and especially qualitative control of bank assets, became a central topic in Williams's reasoning: Central Banks should be prompt and able to use all their discretionary powers to exert credit control, without being inhibited by rigid rules in the selection of bank assets eligible for rediscount: "There must be credit control [...]. The choice is merely 
between better or worse credit control [...]. Under such conditions there is no need of bank reserves, either by the member banks or the central bank; the sole test of the workability of the system is the quality of the assets of the member banks" (Williams 1932b: 135 and 137).

The Fed had been established with the aim of making the supply of credit most efficient; the crisis showed the vital role of qualitative control of bank assets. Yet the criteria of Fed's supervision over the banking system should be shaped along a wider set of objectives. While Williams did not use Currie's term of Commercial Loans Theory, the affinities were nonetheless explicit:

It would be untrue to say that the founders [of the Fed] were unaware of the necessity for control. They prescribed safeguards, but not the proper ones. There is deeply imbedded in the Act the philosophy that member banks credit can be controlled by prescribing the uses to which central bank credit shall be put; and further, that if central bank credit is confined to these proper uses there will be no problem of control. It has taken some eighteen years of experience, including two major booms and depressions, to reveal the fallacies inherent in this philosophy; and notwithstanding the revelations, the philosophy persists strongly in the bill now before the Glass Committee (Williams 1932b: 137-138).

To reverse the powerful deflationary tendencies at work, the Fed should undertake a sudden and bold program of monetary expansion: "Vigorous openmarket operations" should be enacted "to reduce rediscounts of member banks and to increase the supply of purchasing power". At the same time, Williams urged "the substantial reduction or cancellation of war debts and the scaling down of trade barriers" (Williams 1932b: 157). Williams was also more explicit than 
Viner in detailing the type and the amount of market operations the Fed should start up in order to reverse deflation. The most urgent problem was to get the banking system out of debt by buying securities stocked in the balance sheets of banks. This would encourage new loans and circulation of money and upgrade the quality of assets. The stock of securities of the Fed should reach a minimum of $\$$ 1.6 billion, which meant doubling the current Fed holdings (Wright 1932: 249).

Laidler and Sandilands (2002; 2003) have described how accurately this suggestion matched the 1932 Harvard memorandum by Currie, Ellsworth and White, which Williams was probably very well familiar with. Moreover, this unpublished document contained most of the recommendations prepared by several participants in the Chicago conference and inspired by Williams and Viner. These recommendations had been sent by telegram to President Hoover at the end of the conference. In addition to open market operations and the easing of international monetary relations (war debts and tariffs), the Chicago telegram urged Hoover to keep a steady flow of public works expenditures. It also stressed the need to widen the range of assets eligible for rediscount by commercial banks to include, among others, government securities. Viner underscored the crucial connection between government spending, credit expansion and the growth of money supply, a typical monetarist argument for fiscal deficits as an effective means to put money into circulation (Tavlas 1997, 1998a, 1998b). This focus on fiscal expenditures as an accompanying measure to open market operations was even clearer in the Harvard memorandum, which stressed the need for the Government to undertake a "program of public construction on a nationwide scale." The main argument was to ensure that the money put in circulation would encourage adequate expenditures:

Some people feel that an increase in means of payments would have no perceptible effect since, they say, there is plenty of money now; the real difficulty is in getting it spent. We can dispose of this objection very 
briefly by pointing out that we have provided for the spending of the increased means of payments by linking the plan for deposit expansion to one providing for public works with no immediate rise in taxes. If there is one point on which everyone is agreed, it is that any money borrowed by public bodies will be spent (Currie, Ellsworth and White 1932 [2003]: 275-6).

In his Chicago speech, Williams had somehow downplayed the role of fiscal policy. By contrast, Viner had been one of the first American economists to justify fiscal deficits in a depression and to dismiss the dogma that public budgets should always be balanced at the end of a fiscal year. Yet, in their campaign for antidepression policies, Viner and Williams agreed that the best way toward recovery was an extensive use of open market operations. The crisis had come from the heart of the banking system and deflation was driven by the contraction of credit and demand deposits by commercial banks, which were desperately trying to get out of debt. To stimulate credit creation, banks should be provided with excess reserves.

The recommendations of the Chicago Conference did not go unheard. One month later, the Glass-Steagall Act introduced the option to keep Federal Treasury Bills and other non short-term commercial paper in banks' reserves. In the spring of 1932 the Federal Reserve Board began a massive campaign of purchases in the open market, pumping almost 1.1 billion dollars into the system (Meltzer 2003: 358-363). In August, interest rates returned to previous year levels and the Open Market Purchases Committee decided to stop the purchase of securities. ${ }^{14}$ However, this program failed to attain the desired expansion of credit

\footnotetext{
${ }^{14}$ The main outcome of the open market operations carried out in the spring of 1932 was to lower the member banks' demand and the rate for rediscounting within the Fed to the level of August 1931. According to the Riefler-Burgess doctrine (Burgess 1927) which had guided the Open Market Purchases Committee's action since the 1920s, that was the desired result and the committee decided to cease operations (Friedman and Schwartz, 1963: table 17).
} 
by member banks of the Fed system. At the same time, a new wave of bank failures began fuelled by depositors' panic: from 1930 to 1933, one third of U.S. commercial banks closed. Internal and external drains on gold reserves imperilled gold convertibility and produced a further reduction of the money supply. On March 6, 1933 President Roosevelt declared, through the Emergency Banking Act, a week of bank holiday and the suspension of dollar convertibility. The United States left the gold standard system and were determined to pursue antidepression policies without the threat of gold drains.

In the following months, Viner and Williams were called for advice by the Farm Credit Administration and the Federal Reserve Bank of New York, respectively. On March 1934, Viner was appointed special assistant to the Secretary of Treasury Henry Morgenthau, Jr. and recruited Currie, White and other young economists from Harvard. The four Harvard economists were thus offered the opportunity to directly affect the policy-making process and influence government decisions in response to the contraction.

\section{A monetary framework for fiscal policy}

The failure of the 1932 Open Market Purchase Program was not a surprise to the four Harvard economists: they were aware that banks could use the newly acquired reserves to strengthen their balances, without necessarily expanding the money supply or reviving credit conditions. Monetary policy alone did not suffice to foster recovery.

The appearance of excess reserves came as a distinct shock to many monetary theorists in the early thirties. Much of previous monetary theory had been built on the assumption that the banks would always be loaned up. But it became unmistakably clear, as 
bank reserves expanded, that bankers were interested in the quality as well as in the quantity of their assets, and rather than assume undue risks would hold their reserves idle. It was at this point that monetary and fiscal policy joined hands. The financing of deficits combined with pressure through reserves, affords an avenue for expansion of bank assets and deposits accompanied by a decline in interest rates. In addition to the money thus created, government borrowing provides an outlet for old deposits which might otherwise remain idle rather than assume the risks of investment in depression (Williams 1942: 237).

According to Williams, the transmission mechanism was expected to run from bank reserves (affected by open market operations) to short term rates and then to long term rates, fostering investments and aggregate demand. Since the 1920s, the stock of financial assets in the portfolios of banks had been growing, while commercial paper had been declining. Thus, an increase of reserves was likely to foster bank's demand of all the types of assets they held, both short and long term. The possibility to hold treasury bonds as a reserve eligible for rediscount strengthened bank's asset position and lowered interest rates.

Viner's view was that the 1932 Fed's policy had not been strong enough and had overlapped with (but not added to) the action of the Reconstruction Finance Corporation. While succeeding in checking the speed of the decline, the program of monetary expansion had not been able to reverse the powerful deflationary forces at work.

It is often said that the federal government and the Federal Reserve system have practiced inflation during the depression and that no beneficial effects resulted from it. What in fact happened was that they made mild motions in the direction of inflation, which did not 
succeed in achieving it, did not succeed even in accomplishing "reflation," but which probably did slow up somewhat the rate of price decline. The loans of the Reconstruction Finance Corporation, in so far as they involved new credits instead of substitution of sound for unsound credit, the open market purchases of the Federal Reserve Banks, have been in the main but two different aspects of a single operation [...].

At no time, moreover, since the beginning of the depression has there been for as long as four months a net increase in the total volume of bank credit outstanding. On the contrary, the government and Federal Reserve Bank operations have not nearly sufficed to countervail the contraction of credit on the part of the member and non-member banks. There has been no net inflation of bank credit since the end of 1929. There has been instead a fairly continuous and unprecedentedly great contraction of credit during this entire period (Viner 1933a: 21- 22).

An overly negative judgment was also expressed by Currie:

It is generally held that the reserve administration strove energically to bring about an expansion throughout the depression but that contraction continued despite its efforts. Actually the Reserve administration's policy was one of almost complete passivity and quiescence (Currie 1934a: 146-147).

This point of view contrasted with Williams's more moderate interpretation. According to Williams, the Fed's 1932 operations produced some important results, first, by "strengthening the capital structure and the general condition of the banks," and second, by "increasing member bank reserves in the hope of 
stimulating through persistent pressure of huge excess reserves bank loans and investments and the consequent creation of new bank deposits." Williams concluded that "the Fed performed very well in its capacity to act as the fiscal agent, assisting the Treasury and financing through Treasury security issues the Government's expenditures, including the emergence spending program." The only expectation that the 1932 turn of the Fed monetary policy failed to materialize was the revival of private investment. According to Williams, the explanation for this failure did not lay within the banking system. It would be useful to conjecture "how much excess reserves it would take to break down the bankers' liquidity complex." In fact, "as the excess reserves continued to pile up and attain huge dimensions and interest rates sank to levels never previously reached, it was generally recognized that whatever may have been the defects of central banks' policy, the main trouble laid elsewhere" (Williams 1941 [1949]: 219). Thus the most important factor in the declining flow of investments was the lack of business confidence which turned itself in a sluggish demand for credit.

This conviction paralleled Viner's own interpretation of the inability of monetary policy to foster recovery. According to Viner, a crucial factor in the business cycle had a psychological nature: the cycle basically depended on expectations about the future trend of prices and sales which determined the rate at which firms were willing to make investments, using their own idle funds or applying to banks for access to newly created purchasing power. Viner clearly pointed out that business prospects were self-fulfilling. In spite of an absolute increase in bank reserves, when firms were unwilling to make investments credit expansion could not occur. The result was the piling up of excess reserves. While at the Treasury in 1934, with the help of Charles O. Hardy, Viner conducted an inquiry on the availability of credit in the Chicago Federal Reserve district, showing that banks were not, in the main, rejecting demand for new loans; rather, it was demand for credit which had been declining. Thus, according to 
Viner and Hardy, no credit crunch was occurring at the time (Nerozzi 2007: 49$50)$.

Once the depression had started, it did not provoke a deficiency of purchasing power but, rather, a decline in its velocity, which was likely to move pro-cyclically. Yet, according to Viner, it was not the transaction velocity of money which was relevant in determining the low level of aggregate demand, but rather what he called the final purchases velocity of money, i.e., the rate of use of purchasing power in making final consumption and investment expenditures. These transactions should be distinguished from those which were realized for the transfer of real or financial assets but did not produce income. At least for 1933, Viner was convinced that the latter was significantly lower than the former. ${ }^{15}$

This vision paralleled with the one expounded by Currie in his 1934 book. While blaming the onset of the crisis on the contraction of the quantity of money which had impaired business conditions at home and abroad, Currie thought that the continuation of the crisis after the 1932 monetary expansion was mainly due to the "abnormal loss of confidence" that three years of steep depression had engendered in the business community (see also Sandilands 1990: 49-50). Currie, like Viner, regarded velocity as the crucial factor in explaining the inadequate level of aggregate demand at a time when banks were piling up idle reserves and when interest rates had reached very low figures. Again, it was not the transaction velocity of money which was important, but the income velocity of money, whose calculation for the period 1921-1932 Currie had been the first to

\footnotetext{
${ }^{15}$ An explanation of why money velocity could frustrate reflation and the expansion of income can be found in a letter to Bertil Ohlin: "I accept what you call a 'secondary expansion' through the multiplying influence on purchases of a given increase in the means of payment, but I do not like your explanation of it which makes it seem as if (1) the crude circulation of a given amount of money in a given period of time and (2) its use for what I would call ultimate consumption and investment purchases, are identical in amount. Such relevant data as I have been able to find indicate that this multiplier is small and in some cases may even be a divider, even when the crude circulation is very high. In other words, I do not think that ordinarily the total annual volume of ultimate consumption and investment purchases is much greater than the total average volume of means of payment in existence in a country during that year. During 1933, I feel certain the former was smaller than the latter for the United States" (Viner to Ohlin 1933, Jacob Viner Papers, Seeley G. Mudd Memorial Library, Princeton University).
} 
endeavor (Currie 1933). ${ }^{16}$ According to Currie, the income velocity of money had been declining since 1929, worsening the effects of the contraction of the money supply (Sandilands 1990: 42). The most important cause in the decrease in the income velocity was the worsening of business expectations concerning prospective sales and prices. Once precipitated in this state of affairs, monetary policy could not be the principal means of salvation and ought to be supplanted by other measures, first of all, fiscal policy.

While the first evidences of Viner's advocacy of fiscal policy date back to the summer 1931 and those of Currie and White to January 1932, we noted above that government expenditures were seen at the time as a reinforcing measure to monetary policy. In 1933 the situation had changed in many respects and Viner was one of the first economists to state clearly that a bold program of government expenditures was the best means to foster recovery:

The most promising method, I think, is that of governmental expenditures financed by borrowing from the banking system, with the hope that what the banks lend is newly created credit or credit which otherwise would have remained idle and not funds that would otherwise have been used by private business (Viner 1933c: 133).

I am very much in favor of a program of public works, as a means both of relieving unemployment and of stimulating an upturn in business. It is in this way, and in this way alone, that I would favour deliberate credit expansion under government auspices (Viner to Albert

\footnotetext{
16 Sandilands remarks that "total transaction included intermediate payments as well as an enormous volume of transfer payments, especially the sale and purchase of financial claims [...] Currie argued that there can be a huge increase in transaction velocity with no increase in the income velocity" (Sandilands 1990, p. 39).
} 
W. Luse, 1933, January 24, Jacob Viner Papers, Seeley G. Mudd Library, Princeton University, box 38, f. 6$).{ }^{17}$

This vision continued to steer Viner's activity during his tenure as Special Assistant to the Treasury. After an initial inquiry carried out during the summer of 1934 by his Ph.D. student Simon Leland regarding the total expenses and revenues of the public sector considered as a whole, Viner concluded that the increase in Government expenditures had been compensated by a corresponding decrease on the part of the Federal States and other public agencies. With these figures he tried to convince Morgenthau and Roosevelt that public works had to be decidedly increased (Nerozzi 2007: 55).

At the same time, Viner induced Currie to develop, with the help of Currie's student Martin Krost, the series of the "pump priming deficits" in order to measure their effects on the national income and convince the Administration on empirical grounds of the economic soundness of deficit spending ${ }^{18}$. Currie's statistical studies on the "pump-priming deficit series," which were later developed at the Federal Reserve, provided a theoretical justification to deliberate fiscal deficits and a guideline in the selection of the proper Government expenses and investments in order to enhance the income velocity of money. Currie developed and further refined these inquiries during his activity at the Fed, providing a coherent theoretical and empirical support for a proper fiscal intervention, well before the General Theory came to the United States (Stein 1969: 166; Sandilands 1990: 68-78). The article by Currie and Krost made use

\footnotetext{
${ }^{17}$ Albert W. Luse was Secretary manager of the Chicago Face Brick Bureau. Contrary to Hawtrey's "Treasury view," an increase in Government expenditures would have been effective even without credit creation. The availability of idle funds and bank reserves could be sufficient to support a wide expansion of public expenditures without any subtraction of purchasing power from the private sector. According to Hawtrey, if public work expenditures were not coupled with money creation, they would have displaced private investments. Yet he conceded that some exception could be made when the velocity of money was increasing (Hawtrey 1925: 41-42).

${ }^{18}$ Sweezy 1972: 118; see also Viner to Patinkin, January 15, 1970, cited in Patinkin 1969[2003]: 114.
} 
of the typically Keynesian rationale that business expectations depended on aggregate demand, which, in turn, resulted from the balance between investment and voluntary saving.

While this vision was largely influenced by Keynes's early 1930s writings, the four Harvard economists reacted quite critically to the publication of the General Theory. Viner regarded Keynes's treatment of liquidity preference as an undue simplification of the complex causal relationship between money, interest rates and different types of financial assets (Viner 1936). Currie did not share Keynes's definition of liquidity preference as demand for money; on the contrary, he was positive that liquidity preference could be satisfied by holding short-term interest-bearing assets. Currie criticized what he saw as Keynes's insistence on the interest rate as the principal force influencing the decision to invest. As Sandilands put it, for Currie "business was much more influenced by the state of effective demand, sales, and prices than by the interest rate" (Sandilands 1990: 86). ${ }^{19}$ This criticism of Keynes's exclusive insistence upon interest rates as the only available transmission mechanism running from the money supply to aggregate demand was shared also by Williams, who pointed out that low interest rates should be looked upon from the point of view of lenders, i.e., as a loss of income and a reduced incentive to depart from liquidity preference, and

\footnotetext{
${ }^{19}$ Currie doubted that a general theory could explain individual business cycles. Likewise, he was skeptical of Keynes's proposition that the marginal propensity to save would rise over time, and of Hansen's depiction of a "mature economy" where demand stops growing. Following Knight, Currie considered wants insatiable and potential demand growing. Also, Currie maintained that Keynes confused money and savings, while he preferred to distinguish between the demand for money proper and the demand for interest-bearing assets: the former, together with the money supply, influenced the price level, the latter the interest rate. In sum, Currie judged the General Theory unable to explain cyclical macroeconomic instability. Sandilands wrote that "His own thinking, influenced by Keynes's earlier work, had already provided him with what he regarded as more satisfactory explanations of cyclical instability, which in turn offered a rationale for counter-cyclical monetary and fiscal policy. His analysis and policy conclusions were based on an examination of movements in the money supply and the determinants of its demand (velocity), and of the relationship between an estimated full employment national income potential, the expected full employment level of savings (leakages), and the corresponding combined total of private investment and government net contribution required to offset those leakages" (Sandilands 1990: 86).
} 
thus as depressing aggregate demand. When interest rates were very low, "a wide range of institutions and individuals dependent upon fixed income-yielding investments suffer losses of income whose effects upon their ability and willingness to invest further, their sense of security, and even their ability to maintain consumption, work directly counter to the purpose of the easy money policy" (Williams 1942: 244).

Both Currie and Williams were skeptical of the multiplier. Their own advocacy of fiscal policy and deficit spending rested on the argument that the most important effects of public spending depended upon business psychology. ${ }^{20}$ According to Williams "not the least of our dangers is that of confusing this rather mechanical monetary concept with the deep-seated forces with which we should be mainly concerned in our analysis of the economic effects of deficit spending" (Williams 1941 [1949]: 223). ${ }^{21}$

A program of public works would offer industrial firms a growing outlet for their production, inducing them to use their purchasing power or apply for new credit in order to increase production and start up new investments. Yet, though not independent from aggregate demand, confidence was the main source of business recovery. The public sector could not do the entire work, and the private economy needed to play a major part in increasing the use of the existing purchasing power:

\footnotetext{
${ }^{20}$ As Sandilands put it, the Currie-Krost article "postulated a multiplier (secondary spending) but professed to see no way of predicting its magnitude. The pump priming analogy was dropped [...] and, instead, stress was laid on the phrase 'income-increasing expenditures'" (Sandilands 1990: 176).

${ }^{21}$ While Currie, White and Viner supported fiscal policy and shared a similar vision of the way it worked, we have less clear evidence about Williams's views in this respect: though in his later recollections he placed himself among the early supporters of the pump priming argument designed to restore business confidence and private investments, he dissented from 1938 spending program.
} 
There will not be recovery through the method of inflation unless there is an expansion in the use of means of payments. That expansion will not take place except through the mediation of banks in granting new loans or making new investments, or of individuals in making more rapid use of their existing funds in purchases for consumption or investment. [...]

The Government itself cannot achieve inflation. [...] The American Government can give a stimulus, encourage it, can take a moderate share in it, but the major part must be done by the general public, and it will take the form, as already pointed out, of a speeding up in the rate at which business men use such resources as they still have, and the rate at which they ask and induce banks to create new funds for them (Viner 1933b: 133-134).

Business confidence was a very volatile variable, which the Government should take carefully into account by avoiding measures and practices that alarmed businessmen and fed into their fears about the future. The Harvard economists' opposition to the National Recovery Administration and other structuralist reforms typical of the early New Deal is largely explained by this conviction. Moreover, they fiercely criticized the "mature economy" idea, formulated by Alvin Hansen, stating the inability of modern capitalist societies to provide an adequate volume of private investments. According to this vision, government intervention by means of deficit spending should be regarded as a permanent feature of the US economy, instead of an anti-cyclical device to be reversed in the upswing (Sandilands: 86; Williams 1941, 1942).

The 1937-1938 recession was a crucial moment for the four Harvard economists turned public servants: starting from a quite similar analysis, they came to disagree upon the proper measures that should be undertaken. Budget 
deficits could lead to potentially opposite outcomes: as long as they were able to convince firms that aggregate demand for their products was increasing, they were successful; but as businessmen anticipated future tax increases or were concerned by the growing public involvement in economic activity, private investments were likely to suffer a further decline. Currie and White believed that the first effect would prevail. Currie, especially, gave a prominent contribution to the shaping of the bold program of public expenditures approved by the Congress in April 1938 and attained the support of many others economists and officers, including White. Viner and Williams, on the contrary, thought that the ill devised program of expenditures and the further increase of the public debt delayed any self-sustaining recovery. After having joined their forces for many years within the Administration, Currie, Viner, White and Williams came finally to be enrolled in the two opposite armies engaging the "struggle for the soul of Franklin D. Roosevelt" (Stein 1969, Chapter 6).

\section{Concluding remarks}

Viner, Williams, Currie and White cannot be considered as members of a cohesive research group or a school of thought, and certainly they did not regard themselves as such. Yet, they shared a common set of methodological and analytical views, which were deeply rooted in their training at Harvard during the 1920s. They also shared a vision about what anti-depression policies the United States should enact, and they cooperated within the Administration to promote their introduction.

During the first term of the Roosevelt administration, Viner, Williams, White and Currie focused on the analysis of the causes of the depression and the possible ways to recovery. They soon became influential actors in the policy- 
making process that led to New Deal reforms and stabilization policies, either in monetary, banking, fiscal and international matters.

Since as early as 1932 they urged the administration and the Fed to undertake a program of monetary and fiscal expansion and to strengthen the banking system by means of wider rediscount eligibility for banking assets. Their recommendations influenced the final drafting of the Glass-Steagall Act and other emergency measures. In 1933-1934, Viner and Williams fiercely and successfully opposed Irving Fisher's and George Warren's program of dollar devaluation and drastic increase in the quantity of money. They succeeded in terminating that policy with the Gold Stabilization Act of January 1934. In 1935, Currie was entrusted with designing the new Banking Act, which strengthened the powers of the Fed, provided it with new tools of monetary control, and disentangled its statutory objectives from the Commercial Loans principles in favor of a broad set of stabilization policies. Both Viner and Williams supported this reform in public speeches and within the Administration. In 1936 they urged the Fed to use its newly acquired powers to double banks' reserves to prevent a sudden inflationary spike arising from gold inflows.

In terms of fiscal policy, Viner, Currie and White supported the deliberate resort to budget deficits in order to speed up recovery and restore business confidence; these measures were grounded on a series of statistical data on the effects of government expenditures on income, which were suggested by Viner and researched by Currie and Krost. These ideas inspired the bold program of deficit-financed expenditures enacted by Roosevelt after the recession of 193738. In addition, in 1939 Roosevelt appointed Currie as the first economic adviser to the White House. However, it must be noted that, while Currie and White strongly supported the 1938 spending program, Viner and Williams regarded it as an ill-devised program that would not succeed in restoring business confidence and foster private investments (Nerozzi 2007, 2009a; Williams 1941, 1942). 
While Currie was not directly involved in international economic policy during the 1930s, Viner, White and Williams joined forces in fostering monetary cooperation. They took part in the negotiations for the Tripartite agreement of September 1936, when, for the first time since the crisis, France, Great Britain and the United States committed themselves to cooperate in reintroducing more limited targets of exchange rates stability. In the following years, White, Viner and Williams played a fundamental role in the negotiations that led to the new international monetary order. While Viner took some part in the refinement of the White Plan and publicly supported it, Williams proposed a different approach, known as the Key-Currency approach, focusing on stabilization only between the British pound and the dollar, and allowing other countries to choose their own exchange rate regime. Williams's proposal was also supported by Currie (Nerozzi 2009b); it aroused a lively debate and was later acknowledged by Robert Mundell as a source of inspiration for his theory of Optimal Currency Areas (Asso and Fiorito 2009).

This joint policy action was grounded on the interpretation that the four economists gave of the Great Depression: Currie, Viner and Williams believed that heavy deflationary forces were at work all over the world as a consequence of the war and the post-war settlements, and blamed the onset of the crisis on the ominous policies enacted by the Fed which, in an awkward attempt to curb speculation and preserve adherence to the Commercial Loans criteria, had provoked a sudden monetary contraction at home and abroad. This monetary interpretation anticipated the main lines of the Friedman's and Schwartz's analysis of the depression and, together with the recommendations stemming from the 1932 Chicago Harris Foundation Conference, was credited to have played an important role in the establishment of the so-called Chicago monetary tradition. Laidler and Sandilands considered the analysis put forth by Currie, White, Williams and Viner the proof of the non-originality of the Chicago Tradition. It followed the opportunity to retrace the emergence of an American, 
monetarist, stream of original macroeconomic thought at Harvard, under Young's and Hawtrey's teaching, rather than at Chicago, under Lloyd Mints's and Henry Simons's.

Yet, a point that we would like to emphasise is that the monetary theory proposed by these four Harvard economists differed substantially from the views which were later to be associated with monetarism. Their ideas concerning the way money influenced aggregate demand and how the income velocity of money could offset changes in the money supply contrasted with Friedman's restatement of the quantity theory. Moreover, their interpretation of the deepening of the depression, of the delayed recovery, and of the recession of 1937-38did not correspond to that proposed by Friedman and Schwarz in 1963: the four Harvard economists would have certainly denied that the dictum "money does matter" would apply without specification to the U.S. economy during the 1930s. Real factors such as the fundamental disequilibrium between savings and investments underpinned the working of monetary forces and the strenuous resistance of the "propensity to hoard" on the part of banks, firms and individuals. Gloomy price and sales expectations, together with anti-business taxation, determined a sluggish demand for credit and the collapse of investment expenditures. Their opposition to Irving Fisher's plans of monetary expansion and to the $100 \%$ bank reserves was also strengthened by their advocacy of central banks' discretionary powers against the imposition of any fixed rule. Moreover, their support of deficit spending was based not on the typical monetarist argument that it was an alternative channel to the increase of the money supply, but rather as the most effective means to directly foster consumption and investment expenditures, and thus revive business confidence.

Another point is that this vision had a clear Keynesian flavour and was, indeed, influenced by Keynes's pre-1936 writings. Especially the works of Currie and Williams in the early 1930s showed how much, though not uncritically, the Harvard economists had drawn from Keynes' Treatise on Money. Their focus on 
disequilibrium between saving and investments, and the relevance they attached to long-term rather than short-term interest rates in business cycles and banking activity clearly derived from Keynes. Their advocacy of open market purchases and of pump priming fiscal policy (with reference to the indirect effect of public works expenditures) echoed Keynes's own proposals, especially for the United States (Keynes 1931, 1933). Sandilands has not ignored Keynes's influence on Currie and Currie's specifications about what Keynes was most interesting to him. The debate on the originality of the Chicago monetary tradition and its alleged Harvard roots, however, has somewhat de-emphasized the interpretation of the monetary views shared by these Harvard trained economist in the early 1930s and afterwards.

A final remark concerns the reception of the General Theory by this group of economists. Especially Viner's and William's comments, though not overly unfavourable, highlighted many shortcomings in Keynes's masterpiece. More precisely, they highlighted Keynes's too mechanical multiplier analysis, the excessive simplification of liquidity preference, his lack of attention to the supply side and especially to inflationary problems which were likely to arouse in the wake of full-employment policies. Williams and Viner expressed their scepticism to the Keynesian concept of unemployment equilibrium as a long-term phenomenon, which required extensive and permanent deficit spending to attain full employment. It was probably for this reason that they came to side against the deficit spending program of April 1938. White and Currie never seemed to agree with Williams's and Viner's criticism of Keynesian ideas. Despite all distinctions and divergences, however, these four Harvard economists were an effective channel through which pre-1936 Keynesian theory - as John K. Galbraith put it - "came to America" and merged with a vivid tradition of monetary and macroeconomic research that emerged in the landscape of New Deal's policies. 


\section{References}

Allen W.R. (1993). "Irving Fisher and the 100 Percent Reserve Proposal", Journal of Law and Economics, 9, 2, October: 703-717.

Alacevich, M. (2005), "Post-war Economic Policy for Development: Lauchlin B. Currie and the World Bank in Colombia", Storia del Pensiero Economico, 2005/1: 73-92

Alacevich, M. (2009), The Political Economy of the World Bank: the Early Years, Stanford University Press, Palo Alto, CA.

Asso P.F - Luca Fiorito (2009), "A Scholar in Action in Interwar America: John H. Williams on Trade Theory and Bretton Woods", in R. Leeson (ed.) (2009), American Power and Policy, Palgrave Macmillan, Basingstoke, UK: 180-242.

Barber W.J. (1985). From New Era to New Deal: Herbert Hoover, the Economists and American Economic Policy, (1921-1933), Cambridge University press, Cambridge.

Barber W.J. (1996). Designs Within Disorder: Franklin Delano Roosevelt, the Economists and the Shaping of American Economic policy, 1933-1945, Cambridge University Press, Cambridge.

Bernanke B.S. (1995). "The Macroeconomics of the Great Depression: a Comparative Approach", Journal of Money, Credit and Banking, 27: 1-28.

Bloomfield A. (1992). "On the Centenary of Jacob Viner's Birth. A Retrospective View of the Man and His Work", Journal of Economic Literature, 30, 4, December: 2052-2085.

Carlson, V. (1968), "The Education of an Economist before the Great Depression: Harvard's Economics Department in the 1920s," American Journal of Economics and Sociology, 27, 1, January: 101-112. 
Currie L. (1931a). Bank Assets and Banking Theory, Ph.D. Dissertation, Harvard University Press, Cambridge (MA).

Currie L. (1931b). "Review of Federal Reserve Policy (1920-1930) by Harold L. Reed", American Economic Review, 21, March: 162-164.

Currie L. (1933a). "Treatment of Credit in Contemporary Monetary Theory", Journal of Political Economy, 41, February: 58-79.

Currie L. (1933b). "Member Bank Reserves and Bank Debits", Quarterly Journal of Economics, 46, 2, February: 509-525.

Currie L. (1934a). The Supply and Control of Money in the United States, Harvard University Press, Cambridge (MA).

Currie L. (1934b). "The Failure of the Monetary Policy to Prevent the Depression of 1929-1932", Journal of Political Economy, 42, April: 145-177.

Currie L. (1934c). "A Proposed Revision of the Monetary System of the United States" Submitted to the Secretary of the Treasury, Morgenthau, September 1934, reprinted in Currie (1968).

Currie L. - Krost M. (1935[1978]). "Federal Income-Increasing Expenditures", History of Political Economy, 10, Winter: 534-540.

Davis J.R. (1971). The New Economics and the Old Economists, Iowa State University, Ames.

Eichengreen B. (1992). Golden Fetters. The Gold Standard and the Great Depression, Oxford University Press, New York.

Ellis H.S. (1938). "Some Fundamentals in the Theory of Velocity", Quarterly Journal of Economics, 52, 3, May: 431-472.

Fisher I. (1935). 100\% Money, Adelphy Company, New York.

Flanders M.J. (1989). International Monetary Economics, 1870-1960: Between the Classical and the New Classical, Cambridge University Press, Cambridge. 
Friedman M. and Schwartz A. (1963). A Monetary History of the United States, 1867-1960, Princeton University Press, Princeton.

Friedman M. (1956). The Quantity Theory of Money: a Restatement, in R. Leeson (ed.) (2003), I:31-51.

Friedman M. (1972[2003]). "Comments on the Critics", in R. Leeson (2003)(ed.), I: $145-165$.

Hardy C.O. and Viner J. (1935). Report on the Availability of Bank Credit in the Seventh Federal Reserve District, U.S. Treasury Department, Washington.

Hawtrey R.G. (1925). "Public Expenditure and the Demand for Labour", Economica, 5, March: 38-48.

Hawtrey R.G. (1932). The Art of Central Banking, Longmans Group, London.

Keynes J.M. (1930). A Treatise on Money, 2 vols., Macmillan, London.

Keynes J.M. (1931). "An economic analysis of unemployment", in Wright, Q. (ed.): 1-42.

Keynes J.M. (1933), The means to prosperity, MacMillan and Co., London

Keynes J.M. (1936). The General Theory of Employment, Interest and Money, Macmillan, London.

Keynes J.M. (1937). "The General Theory of Employment", Quarterly Journal of Economics, Vol. 51, 2, February: 209-223.

Laidler D. (1993). "Hawtrey, Harvard and the Origins of the Chicago Tradition", in R. Leeson (ed.) (2003), II: 135-171.

Laidler D. (1999). Fabricating the Keynesian Revolution. Studies of the Interwar Literature on Money, the Cycle, and Unemployment, Cambridge University Press, Cambridge, UK. 
Laidler D. and Sandilands R. (2002[2003]). "An Early Harvard Memorandum on Anti-Depression Policies Written by Lauchlin Currie, Paul T. Ellsworth, and Harry D. White", in R. Leeson (ed.) (2003), II: 253-270.

Leeson R. (2003)(ed.). Keynes, Chicago and Friedman, 2 v., Pickering and Chatto, London-Brookfield.

Leeson R. (2009)(ed.), American Power and Policy, Palgrave-Macmillan, Basingstoke.

Martin P.W. (1931). The Problem of Maintaining Purchasing Power, P.S. King, London.

Mason, E. (1982), "The Harvard Department of Economics from the Beginning to World War II," The Quarterly Journal of Economics, 97, 3, August: 383-433

Mehrling P. (1997). The Money Interest and the Public Interest, American Monetary Thought 1920-1970, Harvard University Press, Cambridge (MA) and London.

Meltzer A.H. (2003). A History of the Federal Reserve, vol. 1: 1913-1951, The University of Chicago Press, Chicago and London.

Nerozzi, S. (2007). "Between Harvard and Chicago. Jacob Viner and New Deal Banking Reforms (1933-1935)", Storia del Pensiero Economico, 2: 29-66.

Nerozzi, S. (2009a), "Jacob Viner and the Chicago Monetary Tradition", History of Political economy, forthcoming, Fall 2009

Nerozzi, S. (2009b), "Building up a multilateral strategy for the United States: Alvin H. Hansen, Jacob Viner and the Council on Foreign Relations", in R. Leeson (ed.), American power and policy: 24-68.

Nerozzi, S. (2011), "From the Great Depression to Bretton Woods: Jacob Viner and International Monetary Stabilization (1930-1945)", European Journal of the History of Economic Thought, Forthcoming March 2011. 
Phillips R.J. (1995). The Chicago Plan and New Deal Banking Reform, M.E. Sharpe, Armonk (NY).

Rees D. (1973), Harry D. White. A study in Paradox, Coward, Mccann \& Geoghegan, New York

Sandilands R.J. (1990). The Life and Political Economy of Lauchlin Currie, Duke University Press, Durham (NC).

Sandilands R. J. (2004), "New light on Lauchlin Currie Monetary Economics on New Deal and Beyond", Special Issue, Journal of economic studies: 170-403.

Sandilands R. J. (2009a), "An Archival Case Study. Revisiting The Life and Political Economy of Lauchlin Currie", in R. Leeson ed., American power and policy: 105-133.

Sandilands R. J. (2009b), "New evidences on Allyn Young's style and influence as a Teacher", in R. Leeson (ed.), American power and policy: 134-179.

Stein H. (1969). The Fiscal Revolution in America, University of Chicago Press, Chicago and London.

Steindl F. J. (1995). Monetary Interpretations of the Great Depression, Michigan University Press, Ann Arbour (MC).

Sweezy A. (1972). "The Keynesians and Government Policy, 1933-1939", The American Economic Review, 62, 1-2: 116-124.

Tavlas G. (1997). "Chicago, Harvard and the Doctrinal Foundations of Monetary Economics", in R. Leeson (2003)(ed.), II: 173-199.

Viner J. (1924). Canada's Balance of International Indebtedness: 1900-1913. An Inductive Study in the Theory of International Trade, Harvard University Press, Cambridge (MA). 
Viner J. (1931). "Problems of International Commercial and Financial Policy", in A. $\mathrm{H}$. Buffington (ed.). Report of the round tables and general conferences at the eleventh session, Institute of politics, Williamstown (MA): 165-193.

Viner J. (1932a). "International Aspects of the Gold Standard", in Q. Wright (1932)(ed.): 3-42.

Viner J. (1932b). "Review of: P.W. Martin, The Problem of Maintaining Purchasing Power", Journal of Political Economy, 40, June: 418-419.

Viner J. (1933a). "Balanced Deflation, Inflation or More Depression", Day and Hour series of the University of Minnesota, 2, University of Minnesota press, Minneapolis.

Viner J. (1933b). "Inflation as a Possible Remedy for Depression", Proceedings of the Institute of Public Affairs, University of Georgia: 120-135.

Viner J. (1934a). How Money is Created in the United States, Unpublished, Viner Jacob, File I, Morgenthau Papers, Box 301, Roosevelt Presidential Library, Hyde Park (NY).

Viner J. (1934b). The Banking Examination Situation, October 1, 1934, unpublished, Viner Jacob, File I, Morgenthau Papers, Box 301, Roosevelt Presidential Library, Hyde Park (NY).

Viner J. (1935). Memorandum on International Monetary Stabilization, unpublished, Viner Jacob, File I, Morgenthau Papers, Box 301, Roosevelt Presidential Library, Hyde Park (NY).

Viner J. (1936a). "Mr. Keynes and the Causes of Unemployment", The Quarterly Journal of Economics, 51: 147-167.

Viner J. (1936b). "Can Depression Be Tempered or Avoided", Lectures in Current Economic Problems, U.S. Department of Agriculture Graduate School, Washington: 31-45. 
Viner J. (1936c). "Recent Legislation and the Banking situation", American Economic Review, Supplement, 26, March: 106-119.

Viner J. (1950). The Customs Union Issue, Carnegie Endowment for International Peace, New York.

White H. D. (1933). The French International Accounts, 1880 - 1913, Harvard University Press, Cambridge (MA).

Wright Q. (1931)(ed.), Norman Wait Harris Memorial Foundation, Reports of Round Tables: Unemployment as a World Problem, University of Chicago Press, Chicago.

Wright Q., (1932)(ed.). Norman Wait Harris Memorial Foundation, Reports of Round Tables: Gold and Monetary Stabilization: Lectures on the Harris Foundation, University of Chicago Press, Chicago.

Williams J. H. (1920a). Argentine International Trade under Inconvertible Paper Money, 1880-1900, Harvard University Press, Cambridge (MA).

Williams J. H. (1920b). "Germany's Reparation Payments - Discussion". American Economic Review, Vol. 10, No. 1, Supplement, Papers and Proceedings, March: 50-57.

Williams J. H. (1928). "Opportunities for Research in International Relations Discussion", Social Science Research Council, Hanover Conference, mimeo.

Williams J. H. (1929). "The Theory of International Trade Reconsidered". Economic Journal, Vol. 39, No. 154, June: 195-209; reprinted in Williams (1949), chp. 2.

Williams J. H. (1931). "The Monetary Doctrines of J.M. Keynes". The Quarterly Journal of Economics, Vol. 45, No 4, August: 547-587; reprinted in Williams (1953a), chp. 11. 
Williams J. H. (1932a). "The Crisis of the Gold Standard", Foreign Affairs, January; reprinted in Williams (1949), chp. 16.

Williams J. H. (1932b). "Monetary stability and the Gold Standard". in Wright (ed.), Gold and Monetary Stabilization, Harris Foundation Lectures, University of Chicago Press; reprinted in Williams (1949), chp. 17.

Williams J. H. (1934). "The World's Monetary Dilemma: Internal versus External Stability", Proceedings of the Academy of Political Science, Vol. XVI, No. 1, April: 62-68; reprinted in Williams (1949), chp. 18.

Williams J. H. (1936). "The Banking Act of 1935". American Economic Review, Papers and Proceedings, March; reprinted in Williams (1949), chp. 15.

Williams J. H. (1937). "The Adequacy of Existing Currency Mechanisms under Varying Circumstances", The American Economic Review, Papers and Proceedings, Vol. 27, No. 1, March: 151-168; reprinted, under a different title, in Williams (1949), chp. 19.

Williams J. H. (1942). "Implications of fiscal policy", American Economic Review, Papers and Proceedings, March; reprinted in Williams (1949), chp. 14.

Williams J. H. (1943). "Currency Stabilization: The Keynes and White Plans". Foreign Affairs, July; reprinted in Williams (1949), chp. 8.

Williams J. H. (1944a). "The Post-war Monetary Plans", American Economic Review, Supplement, Papers and Proceedings, Vol. 34, No. 1, March: 372-384; reprinted in Williams (1949), chp. 10.

Williams J. H. (1944b). "After Bretton Woods", Foreign Affairs, October; reprinted in Williams (1949), chp. 6.

Williams J. H. (1948). "An Appraisal of Keynesian Economics", American Economic Review, Supplement, Papers and Proceedings, Vol. 38, May: 273-298; reprinted in Williams (1949), chp. 1 and Williams (1953a), chp. 3. 
Williams J. H. (1949). Postwar Monetary Plans and Other Essay. Oxford: Blackwell.

Young A.A. (1927). Economic Problems New and Old, Riverside Press, Cambridge (MA).

Young A.A. (1928). An Analysis of Bank Statistics for the United States (19001916), Harvard University Press, Cambridge (MA). 